\title{
EFL Teachers' Perceptions of the Barriers and Opportunities for Implementing eLearning at Afghanistan Universities
}

\author{
Mohammad Naim Rahim ${ }^{1, *}$, Sandaran S. C. ${ }^{2}$ \\ ${ }^{1}$ Department of English Language, Kunduz University, Afghanistan \\ ${ }^{2}$ Faculty of Social Sciences and Humanities, Universiti Teknologi Malaysia, Malaysia
}

Received June 24, 2020; Revised October 1, 2020; Accepted November 7, 2020

\section{Cite This Paper in the following Citation Styles}

(a): [1] Mohammad Naim Rahim, Sandaran S. C., "EFL Teachers' Perceptions of the Barriers and Opportunities for Implementing eLearning at Afghanistan Universities, "Universal Journal of Educational Research, Vol. 8, No. 11C, pp. 97 - 104, 2020. DOI: 10.13189/ujer.2020.082311.

(b): Mohammad Naim Rahim, Sandaran S. C. (2020). EFL Teachers' Perceptions of the Barriers and Opportunities for Implementing eLearning at Afghanistan Universities. Universal Journal of Educational Research, 8(11C), 97 - 104. DOI: 10.13189/ujer.2020.082311.

Copyright $\mathrm{O} 2020$ by authors, all rights reserved. Authors agree that this article remains permanently open access under the terms of the Creative Commons Attribution License 4.0 International License

\begin{abstract}
Learning is implemented as an educational approach in teaching and learning EFL globally. Although, eLearning is said to enhance EFL education, there are still barriers and opportunities for the use of this approach that needs to be investigated. While there is wide research on eLearning, within the context of Afghanistan EFL practices, there is a need for more investigations. The current study aimed to investigate the perceptions of Afghan EFL teachers' perceptions, barriers and opportunities of implementing eLearning at universities. The study applied a qualitative approach. The respondents were $6 \mathrm{EFL}$ teachers, purposefully selected from the English Department of a particular university in Afghanistan. The data were collected via semi-structured interview. Thematic analysis was used for coding. The findings showed that the teachers have a basic understanding of eLearning as well as its potentials for use at university-level EFL teaching and learning. It is also highlighted that the educational system has been transformed, and that eLearning provides a practical and visual language teaching with an anytime/anywhere learning opportunities. Some of the major barriers of eLearning implementation mentioned by the teachers include lack of regular supply of electricity, low speed internet, limited access to ICT tools, and lack of computer labs. The EFL teachers' interest to implement eLearning shows they are motivated to use eLearning in the EFL
\end{abstract}

classroom, but due to the barriers, it is a challenge that the teachers find it hard to overcome as one of the biggest challenges is the lack of regular supply of electricity. The findings could help the Ministry of Higher Education of Afghanistan to consider this as an urgent need for changes to be made especially as in the new normal, COVID-19 pandemic era, due to digital disruption, virtual classrooms have become the norm worldwide. Without proper ICT systems, power supply and skills, both the teachers and students in Afghanistan would be greatly disadvantaged.

Keywords eLearning, EFL, Perceptions, Education, Barriers, Opportunities, COVID-19

\section{Introduction}

Today, distance education, virtual learning, personalized learning, blended learning, education IR 4.0, and many other learning models are turning to be the most common approaches in educational practices. In line with these educational advancements, eLearning is common in EFL/ESL practices. eLearning can be traced back to the 1980s (Harasim, 2000), and the term eLearning (electronic Learning) refers to the implementation of an educational design that enhances instruction effectiveness and quality 
by incorporating technology which improves teaching, assessment and the learning process as a whole (Amador, Nobre, and Barros, 2016). Since the emergence of computer usage, the term CALL (Computer Assisted Language Learning) is known among language teachers and learners. Later, while the development of technology reached its advanced stage, MALL (Mobile Assisted Language Learning) became a considerable approach used in language learning and teaching arenas. Currently, as part of Information and Communication Technology (ICT) applications, not only mobile but other technological tools are used to facilitate learning. And this has become part of the new normal in the COVID-19 pandemic times due to digital disruption in educational practices whereby teachers and students are now part of virtual classrooms (Ang \& Sandaran, 2020). Despite the need for the use of technology in language teaching and learning, some countries such as Afghanistan are lagging on these educational innovations.

There have been many studies on eLearning in recent years, such as Jebreen, (2017), Hussain et al (2018), Al-Azawei, Parslow, and Lundqvist (2016), O'Doherty et al (2018), Rajaee Harandi (2015), and Lakbala, (2015). Reviewing the previous studies, some research gaps have been identified. For instance, most of the studies that investigated on eLearning practices used the quantitative approach, while very few used mixed methods, and limited number of them adopted the qualitative approach. The current study adopts a qualitative approach to get an in-depth understanding of the issue as well as to address the research gaps. Based on personal experience, observations and discussions with EFL lecturers in Afghanistan, as well as on our review of previous studies that have investigated different contexts and approaches to eLearning practices, we find that there is a real need to investigate EFL education in relation to eLearning practices in Afghanistan, and most specifically at university level. This study is motivated by the situation in Afghanistan that is based on the experience of one of the researchers who has been a lecturer at a university in Afghanistan. Therefore, the current study aims to investigate the perceptions of EFL teachers on the use of eLearning to determine the barriers and opportunities of implementing eLearning at university-level education in the EFL context of Afghanistan.

\section{Implementing eLearning in the EFL Teaching and Learning Environment}

In this section, some of the key concepts within the context of the previous studies are discussed including paradigm shift in education in the $21^{\text {st }}$ century and eLearning, major barriers of eLearning in $21^{\text {st }}$ century, and transition from traditional approaches to eLearning, and
ICT literacy of EFL teachers.

\subsection{Paradigm Shift in the $21{ }^{\text {st }}$ Century Education and eLearning}

The educational paradigm of the $21^{\text {st }}$ century is becoming gradually digitalized and this is a reason why EFL teachers need to be more aware of the needs of the learners to determine approaches which engages and supports self-learning. And in the new normal of the COVID-19 pandemic period, there is an even greater need for ESL/EFL teachers to be more up-to-date with eLearning practices not only because of the shift to virtual classrooms, but also because eLearning is an invaluable platform that is user-friendly and effective and above all, safe as it is managed by the institutions which ensures security breaches do not become an issue as with other external online platforms such as ZOOM. In addition, eLearning's chat, forum, and other applications can help for two-way interaction between teachers and students. Uppal, Ali and Gulliver (2017) elaborate that applying eLearning approaches throughout in each unit of a program can be used in reciprocal ways where students can provide feedback to the teachers, receive feedback from the teachers, and also see how their feedback informs subsequent practice and delivery in real-time, rather than for the potential benefit of future students. These aspects highlight a fact that eLearning approaches provide the opportunity for the learners to be involved in the teaching-learning activities where it improves the teaching and learning process that is aligned with the needs of the $21^{\text {st }}$ century.

Online environments provide opportunities in the way a foreign language is learned. Language evaluation practices are often inadequate in the range and manner in which they are allocated in the eLearning environment (Gillett-Swan, 2017). Therefore, it can be said that eLearning approaches facilitate foreign language learners with a set of interactive tasks through which the learners are involved in every stage of language learning and evaluations. For instance, the learners may have group presentations instead of individual tasks and this assists them in terms of group assessments. Currently, learners who have been deciding to assume eLearning indicated a preference for online assessments. However, Stoessel et al (2015) stated that additional incorporations or the family commitments may restrict learners' ability to engage in alternative and perhaps preferred face-to-face or blended learning approaches. In addition, technology attempts to transform the passive atmosphere into a more dynamic context. Whereas Rajaee Harandi (2015) claimed that learners' requirements changed since they are involved in these new technological innovations. This indicates that learners are aware of their authentic needs of language learning and this need can be fulfilled by eLearning. In addition, paradigm-shifting in language teaching methodology is an 
issue for teachers. As Domingo and Garganté (2016) stated that pedagogy is transformed from a teacher-centered to a student-centered approach. This has provided more tasks and choices for learners and their learning. Therefore, eLearning in addition to providing all these multiple-choice tasks for the learners, addresses the authentic concerns of EFL education.

According to Hussain et al (2018), in tracking student engagement in different educational activities, eLearning encourages high-quality learning and comprehensive analysis of student engagement can help to minimize course dropout rates. Based on the findings of this study, one of the opportunities for effective implementation of eLearning in teaching and learning a foreign language is facilitating anywhere and anytime education. In fact, technology most particularly eLearning provides this opportunity for foreign language learners to have flexible learning platforms. The current study also tries to highlight the major opportunities of implementing eLearning in EFL education at Afghanistan universities. Consequently, when we are discussing personalized learning, students can decide what to learn and how to learn. Also, eLearning as an educational approach currently provides the opportunity for both EFL teachers and the learners to decide on the most appropriate contexts and the accurate contents to teach and learn. Gillett-Swan (2017) stated that educational policy developers are becoming increasingly aware of the diversity of the potential of eLearning in current times. They are looking into ways of providing a range of options for learners' engagement and increasingly flexible teaching approaches such as eLearning can provide multiple pathways and opportunities for EFL education.

\subsection{Major Barriers of eLearning in $21^{\text {st }}$ Century}

Some of the major challenges of eLearning in $21^{\text {st }}$ century are lack of technical skills in eLearning, lack of development of the electronic contents by faculty members, and lack of interest and commitment among faculty members to use eLearning. Table 1 provides a summary of prior studies on the major barriers of eLearning implantations associated with different countries. It highlights the main barriers within different studies that investigated the barriers of implementing eLearning.

Table 1. The Barriers of Implementing eLearning

\begin{tabular}{|c|c|c|c|}
\hline No. & Study & Country & Barriers \\
\hline 1 & $\begin{array}{l}\text { Mahmoodi-Shahrebabaki } \\
\text { (2014), }\end{array}$ & Iran & $\begin{array}{l}\text { Lack of government support, lack of public awareness, high costs of eLearning, } \\
\text { collectivist society, low-speed internet, and filtering. }\end{array}$ \\
\hline 2 & Qureshi et al (2012), & Pakistan & $\begin{array}{c}\text { Electricity failure, English proficiency, lack of ICT infrastructure, curriculum } \\
\text { alignment with eLearningapproaches, encouragement for eLearningmethods, and } \\
\text { unsuccessful integration of eLearning. }\end{array}$ \\
\hline 3 & Homavazir (2015), & India & $\begin{array}{l}\text { Costs savings are not being universally realized, cyber-crime, course load, course } \\
\text { updating, revision, and consistency across departments. }\end{array}$ \\
\hline 4 & Wang et al (2018), & China & $\begin{array}{l}\text { Lack of favorable eLearningenvironments, poor infrastructure, financial } \\
\text { constraints, inadequate support, and lack of eLearningskills. }\end{array}$ \\
\hline 5 & Soydal et al (2011), & Turkey & $\begin{array}{l}\text { Significant differences in terms of age and title, differences among different } \\
\text { departments in terms of eLearningperceptions, and the needs of training for } \\
\text { academic staffs. }\end{array}$ \\
\hline 6 & Aljaber (2018), & Saudi Arabia & $\begin{array}{l}\text { Challenge of ensuring educators possesses the right skills to operate technology, } \\
\text { misalignment of curricula and ICT, resistance to change, and the influence of the } \\
\text { culture. }\end{array}$ \\
\hline 7 & Jabreen (2017), & Jordan & $\begin{array}{c}\text { Lack of students' awareness, students' anxiety, teachers' resistance to change, and } \\
\text { lack of capacity building opportunities. }\end{array}$ \\
\hline
\end{tabular}




\subsection{Transition from Traditional Approaches to eLearning}

Transition from traditional approaches of teaching and learning to technology-enhanced methods is still a barrier that teachers and students face. According to Al-Azawei and Lundqvist (2015), in terms of transition from traditional learning to eLearning, when teachers implement eLearning, they should carry out activities, implement interactive learning and evaluate themselves, because these activities help them understand the importance of the eLearning approaches. And this measure would help them understand their students' needs and issues about eLearning practices in the EFL classrooms. Schmidt, Tschida, and Hodge (2016) indicated that most of the face-to-face learning practices can be adapted into the eLearning context. According to their investigations, it is not simply the case of applying a one size fits all which is what teachers who are relatively unfamiliar with eLearning practices do. Similarly, Orlando and Attard (2015) stated that when it comes to technology, e-teaching depends on the means of technology in use at the time and the curriculum content being taught. When teachers address these concerns, they can help to reduce the barriers by aligning the teaching content with the eLearning module, which makes it better suited for the educational setting.

In addition, blended learning is a better alternative for traditional approaches. Since it provides classrooms with online platforms and face-to-face learning. According to Lalima and Dangwal (2017), blended learning is an innovative model of teaching and learning which enhances both traditional classrooms and ICT integrated education. Therefore, this approach can help institutions and the instructors to adopt blended learning and transit the traditional approaches to eLearning context. Furthermore, Ruliah, Syahrial, Muchtar (2019) indicated that the traditional face-to-face approach which is teacher-centered learning unbaled the instructors carry the educational materials and achieve the course objectives. Whereas, computer assisted learning help them with different models of education including medias, interactive tasks, and visual aids to enhance the education process and deliver the educational materials effectively. This indicates that there are alternative approaches to transit from traditional approaches to eLearning.

\subsection{ICT Literacy of EFL Teachers}

For a successful eLearning implementation in EFL classrooms, ICT knowledge for EFL teachers is necessary. According to Jebreen (2017), faculty members need to receive training on professional development, education online, and requirements to encourage teaching online. This will have impact on teachers to pave the way for a successful transition from traditional approaches to eLearning. eLearning has the potential to provide interactive language learning platforms. Thus, if EFL teachers have enough knowledge of ICT and new educational innovations, then they can easily integrate the $21^{\text {st }}$ century skills, i.e. collaboration, cooperation, communication, creativity, and critical thinking which are the core values for EFL education today. Al-Azawei, Parslow, and Lundqvist (2016) stated that a key barrier for implementing eLearning is lack of ICT knowledge of the teachers where the absence of technology leads them to use the traditional approach. Kisanga and Ireson (2015) state that successful eLearning implementation is one means for solving some of the concerns of teaching and learning. This affirmation supports the idea that empowering eLearning implementation particularly in the EFL education in Afghanistan is necessary especially with the practices in the new normal and virtual classroom environment. Taking into consideration the context of EFL classrooms in Afghanistan, our initial observations of Afghanistan EFL teachers show that they lack ICT knowledge due to the lack of ICT tools and guide for better understanding of technology integrated instructions. Therefore, the current study aims to identify the perceptions of EFL teachers on the barriers and opportunities of implementing eLearning in the context of Afghanistan tertiary level institutions.

\section{Methodology}

The study applied qualitative approach with semi-structured interviews using a purposive sampling technique. The purpose of the qualitative approach is to understand, from within, the subjective reality of the research participants (Creswell,2017). Semi-structured interview enables us to understand the users' perceptions of their use of eLearning. Blandford (2013) also stated that one growing trend is the application of qualitative methods to better understand the use of technology in context. Since the study is investigating the perceptions of the field's practitioners, therefore, Zorn (2010) also indicated that the purpose of applying a semi-structured interview is the classification of insights into the topic from the perspective of participants. The purpose of using a purposive sampling technique is to select the respondents from the discipline practitioners who could be able to perceive the issue based on the practices and understanding of the authentic concerns.

6 EFL teachers from the English Department of a particular university in Afghanistan were selected as respondents of the study. Blandford (2013) also stated that the choice of approaches to recruitment depends on the purpose of the study and the kinds of respondents needed. In the current study, direct contact is used to recruit the samples. The semi-structured interview is conducted face-to-face and e-interview (Facebook Messenger, WhatsApp, and Telegram). E-interview is getting to be the common tool of the data collections. As Rode (2011) stated 
that new technologies developed, they allow new possibilities for fieldwork-remote interviews, participant-observation through games, or blogs, or virtual worlds, and following the lives of one's informants via twitter. Similarly, Blandford (2013) also stated that the possibilities are seemingly endless and growing. The limit may be the imagination of the research team. The interviews are transcribed and thematically coded by identifying the patterns and themes. Braun and Clarke (2013) described that thematic analysis is the process of identifying patterns or themes within qualitative data.

\section{Findings and Discussions}

The study aimed to answer two main research questions: How EFL teachers perceive the use of eLearning at university-level education in the EFL context of Afghanistan? and What are the barriers and opportunities for implementing eLearning at university-level education in the EFL context of Afghanistan? Applying qualitative approach, data are collected via a semi-structured interview. The main themes identified include, eLearning awareness Among EFL Teachers in Afghanistan, eLearning enhances EFL education, preferred eLearning tools by EFL teachers, eLearning and EFL teachers' interaction with students, lack of infrastructures, eLearning Support by EFL teachers, and eLearning as an ideal approach of EFL practices in the Afghanistan tertiary context.

\section{1. eLearning Awareness Among EFL Teachers in Afghanistan}

The findings of the study highlight that there is a basic understanding of the use of eLearning at university-level education in the EFL context of Afghanistan. All the teachers interviewed confirmed that they are applying eLearning in their EFL classrooms. As one of the EFL teachers stated, "I use eLearning accordingly whenever the tools are accessible at university". In addition, the findings declare that there is also awareness about eLearning itself among EFL teachers. As an EFL teacher stated that "eLearning is a kind of teaching which is carried out by the help internet and other electronic devices."

\section{2. eLearning Enhances EFL Education}

In terms of how eLearning usage would facilitate EFL education, most of the EFL teachers stated that teachers in Afghanistan are motivated to use eLearning. For example, one teacher stated, "In recent decades, the educational system has been transformed, and around the world educational institution used eLearning approaches. ELearning can help both teachers and students to acquire recent information on language teaching and learning".
This indicates that the paradigm shift in education is motivating the EFL teachers in Afghanistan towards the use of technology-integrated approaches to enhance EFL education. Therefore, most of the EFL teachers agreed that eLearning enhances EFL education. As one of them strongly stated, "It would best facilitate the acceleration of the language learning process".

Similarly, there are findings from the studies that are aligned with the findings of the current study which stated that the term eLearning refers to the implementation of an educational design that enhances instruction effectiveness and quality by incorporating technology which improves teaching, assessment and the learning process as a whole (Amador, Nobre, and Barros, 2016). This highlights that eLearning has the potential to enhance EFL education. In addition, the findings show that eLearning can facilitate EFL students to be independent learners as well as it will help the teachers in the class to provide their students practical and visual teaching which will be received by the learners very easily. As one of the EFL teachers stated, "Using eLearning, EFL teachers and students are connected 24 hours with each other's and the students have access to the materials that they will study during the classes". Also, most of the EFL teachers stated that "Most of the academic activities are done online, it will prevent time-consuming". This indicates the concerns about reducing time-consuming in EFL education applying eLearning.

\subsection{Preferred eLearning Tools by EFL Teachers}

In terms of what types of eLearning tools are preferred for EFL classrooms, the teachers mentioned web based online resource. For example, one teacher stated, "The teachers should have pointed out, for students, different webs for English language exercise". Also, they stated that EFL teachers should use those webs and online sources as a tool to improve language learning. As an EFL teacher stated, "EFL teachers have to use online resources for improving EFL". EFL teachers also highlighted few tools as eLearning, "For instance, EFL teachers can play some native speakers' videos in order the leaners to learn the correct pronunciation of words as well as to strengthen the students' listening skill". The teachers also stated that students should be given projects and assignments integrated with the use of ICT. As an EFL teacher stated, "The teachers should assign projects and assignments which need online reading for their accomplishment". This indicates that EFL teachers do intend to use the available eLearning platforms for enhancing students' language proficiency. Thus, the teachers' response highlights that technological innovations can enhance learners' interests and motivation, benefit students to access the target language input, provide them with more interaction opportunities and feedback (Golonka et al, 2014). 


\section{4. eLearning and EFL Teachers Interactions with the Students}

In terms of interactions with the students via eLearning, EFL teachers stated that students' and teachers' interaction is a core factor for language learning. As one of the EFL teachers said, "Interaction with students is crucial, without interaction the language learning arguably ineffective". It is also elucidated that eLearning interactions with the students mean to guide the students on how to use eLearning resources and seek out valuable and reliable information. In addition, the teachers stated that eLearning facilitates effective interactions between students as well as teachers, e.g. "eLearning will pave the best way for better interaction. Through eLearning, I can communicate with my students very well. I can share my teaching materials, videos, audio, and slides".

This is aligned with the assumed barriers in the problem background of the current study which is stated that students are not willing to learn a foreign language in the traditional way of chalk and talk anymore since they are born in the age of technology and technological trends. Like the findings of the current study, the findings by Aljaber (2018) in Jordan also indicated that barriers related to the technology-integrated approaches gap incline to take on a diverse meaning in different regions and countries. For instance, in developed countries, this gap is demonstrated by limited knowledge of the ICT by both teachers and students, whereas, in developing countries like Afghanistan, it is can be said that lacking in ICT infrastructures and knowledge and skills of the teachers and students, is a key barrier.

\subsection{Lack of Infrastructure}

All the teachers interviewed expressed that they face a lack of infrastructure for using eLearning at university-level education in the EFL context of Afghanistan. For instance, due to the lack of eLearning resources such as projectors, computers, high-speed internet, electricity challenge, and lack of computer lab availability, they tend to not use eLearning much. As one of the EFL teachers stated that "I have not implemented e Learning in my teaching, while the expected barriers are lack of internet, computers, projectors and eLearning resources which causes student's incompetence in using online resources". However, there are steps in progress by the Ministry of Higher Education in Afghanistan (MoHE, 2015) that attempt to facilitate universities with eLearning tools and potentials.

Despite the response of some of the teachers that EFL teachers and the students use eLearning, the findings of the current study highlight that there are challenges in implementing eLearning at university-level education in the EFL context of Afghanistan. For instance, both teachers and students do not have access to internet, electricity, computers and standard classrooms. As one of the EFL teachers also stated, "Implementing eLearning requires access to a stable and strong internet connection and electronic technologies such computers, tablets and smartphones, unfortunately, Universities do not have such equipment and facilities". They also added that ICT literacy of the teachers is a factor for the implementation of eLearning. As one of the EFL teachers stated, "Teachers and students have not been trained about eLearning at university". According to the findings of the study by Al-Azawei, Parslow, and Lundqvist (2016), a key barrier for implementing eLearning is lack of ICT knowledge of the teachers and the absence of technology leads to them using traditional approaches.

\section{6. eLearning Support by EFL Teachers}

There are enough potentials not only by the EFL teachers, the organization but also by the ministry of higher education that have taken practical steps towards the improvement of eLearning implementation at university-level education in the EFL context of Afghanistan. The teachers also mentioned the students' perceptions positive towards adopting eLearning. As one of the EFL teachers stated, "Students feel happy and confident when they utilize eLearning inside or outside of the classrooms". This shows that there are motivations for the use of eLearning even by the EFL learners. Similarly, one teacher stated that "Whenever I implanted some eLearning in the past, my students had positive perceptions". Jebreen (2017) also stated that for restructuring the educational development even in developing countries, eLearning has the potential and efficiency. One teacher explained that "ELearning implementation is a good tool in teaching and learning EFL. We should start implementing eLearning in our university gradually. First, we should start with easy tools then we can practice more difficult ones".

\section{7. eLearning as an Ideal Approach for EFL Education}

The findings show that the teachers consider eLearning as an ideal method for teaching and learning EFL. As one teacher stated, "Everything has been transformed including the educational system, many new approaches and methods have been introduced to learning and teaching". Another added "Among them, using technology inside the class and outside of the class is taking place to improve the language teaching and learning process". Thus, eLearning methods are tied up with technology and technology brings ease particularly in the teaching and learning of EFL. This indicates that EFL teachers are moving toward the paradigm-shift in EFL education. One of the teachers also added that "eLearning makes students quick respondents to a problem as well as it helps teachers keep a close relationship with his/her students and to be well-aware from the students' progress". This is how eLearning is considered an ideal approach to EFL 
education. Hussain et al (2018) explain that tracking student engagement in different educational learning activities, eLearning encourages high-quality learning, and comprehensive analysis of student engagement can help to minimize course dropout rates. Similarly, a teacher stated that "Today, the internet is infinite, and the eLearning is one of the best ways to learn English and to get in touch with native speakers".

In summary, based on the findings, EFL teachers perceived that there is a basic understanding of the eLearning as well as potential to use it in EFL education. They also added that educational system has been transformed, eLearning can help both EFL teachers and the students, eLearning provides practical and visual language teaching, and anytime/anywhere education. In terms of barriers and opportunities for implementing eLearning at university-level education in the EFL context of Afghanistan, the teachers stated lack of infrastructures, namely, electricity, low internet speed, limited access to ICT tools, and lack of computer labs.

\section{Conclusion}

This study set out to identify the barriers and opportunities for implementing eLearning in the Afghanistan tertiary level EFL context. Based on six semi-structured interviews of EFL teachers, the findings indicate that EFL teachers perceive eLearning as a model that enhances EFL education. They see eLearning as a tool that helps both teachers and students and provides visual language learning tasks. In addition, it is highlighted that eLearning saves time as it provides anytime/anywhere education. Thus, it can be said the teachers are aware of the potentials of eLearning usage in the EFL classroom at universities in Afghanistan. Some of the barriers of implementing eLearning at university-level education in the EFL context of Afghanistan mentioned by the teachers include, lack of infrastructures, lack of computer labs, poor internet connections, and lack of regular supply of electricity, all of which are considered as infrastructure challenges. Our findings highlight the need for better ICT facilities, and measures to enhance the knowledge and skills of EFL teachers to enable the use of eLearning as a part of tertiary level EFL classrooms in Afghanistan. But due to some of the barriers mentioned, the teachers consider this a great disadvantage for the Afghanistan EFL context as without the limitations, teaching and learning of English could be a much better experience and practice for the teachers and students.

\section{REFERENCES}

[1] Afghanistan, Ministry of Higher Education. (2015). $O B E$,
SCL and eLearning Workshop. Kabul: Ministry of Higher Education.

[2] Ang, S., R., and Sandaran, S., C. (2020). Teachers' practices and perceptions of the use of ICT in ELT classrooms in the pre-covid 19 pandemic era and suggestions for the 'new normal. LSP International Journal 7(1). DOI: 10.11113/1spi.v7n1.100.

[3] Al-Azawei, A., Parslow, P., \& Lundqvist, K. (2016). Barriers and opportunities of ELearningimplementation in Iraq: A case of public universities. The International Review of Research in Open and Distributed Learning, 17(5). doi:10.19173/irrodl.v17i5.2501.

[4] Aljaber, A. (2018). ELearningpolicy in Saudi Arabia: Challenges and successes. Research in Comparative and International Education, 13(1), pp. 176194. (doi:10.1177/1745499918764147).

[5] Amador F., Nobre A., and Barros D. (2016). Towards a model of a didactics of eLearning: An application to education for sustainable development. In: Pinheiro $M$ and Simões D (eds) Handbook of Research on Engaging Digital Natives in Higher Education Settings. Hershey, PA: IGI Global, pp.396-415.

[6] Ang, S.R \& Sandaran, S.C. (2020). Teachers' Practices and Perceptions of the Use of ICT in ELT Classrooms in the PreCovid 19 Pandemic Era and Suggestions for the 'New Normal'. LSP International Journal, 7/1, 99-119.

[7] Blandford, Ann. (2013). Semi-structured qualitative studies. In: Soegaard, Mads and Dam, Rikke Friis (eds.). "The Encyclopedia of Human-Computer Interaction, 2nd Ed.". Aarhus, Denmark: The Interaction Design Foundation. Available online athttp://www.interactiondesign.org/encycl opedia/semi-structured_qualitative_studies.html.

[8] Clarke, V. \& Braun, V. (2013). Teaching thematic analysis: Overcoming challenges and developing strategies for effective learning. The Psychologist, 26(2), 120-123.

[9] Creswell, J. W., \& Poth, C. N. (2017). Qualitative Inquiry and Research Design: Choosing Among Five Approaches. Sage publications.

[10] Domingo, M. G., \& Garganté, A. B. (2016). Exploring the use of educational technology in primary education:

[11] Teachers' perception of mobile technology learning impacts and applications' use in the classroom. Computers in Human Behaviour, 56, 21-28. doi: DOI: 10.1016/j.chb.2015.11.023.

[12] Gillett-Swan, J. (2017). The challenges of online learning: Supporting and engaging the isolated learner. Journal of Learning Design, 10(1), 20. doi:10.5204/jld. v9i3.293.

[13] Golonka, E. M., Bowles, A. R., Frank, V. M., Richardson, D. L., \& Freynik, S. (2014). Computational Intelligence and Neuroscience, 2018, 1-21. doi:10.1155/2018/6347186.

[14] Homavazir, Z. F. (2015). 'Impact of eLearning on student learning and employability - A study in India' (dissertation). D.Y. PATIL UNIVERSITY, School of Management.

[15] Harandi, S. R. (2015). Effects of eLearningon students' motivation. Procedia - Social and Behavioral Sciences, 181, 423-430. doi: 10.1016/j.sbspro.2015.04.905.

[16] Harasim, L. (2000). Shift happens: Online education as a 
new paradigm in learning. The Internet and Higher Education, 3(1-2), 41-61. doi:10.1016/s1096-7516(00)0003 2-4.

[17] Hussain, M., Zhu, W., Zhang, W., \& Abidi, S. M. (2018). Student engagement predictions in an eLearningsystem and their impact on student course assessment scores. Computational Intelligence and Neuroscience, 2018, 1-21. doi:10.1155/2018/6347186.

[18] Jebreen, I. (2017). ELearning system - challenges \& barriers: A case study. International Journal of Computing Academic Research (IJCAR), 6(2), 59-66. Retrieved from http://meacse.org/IJCAR/archives/119.pdf.

[19] Kisanga, D., \& Ireson, G. (2015). Barriers and strategies on adoption of eLearningin Tanzanian higher learning institutions: Lessons for adopters. International Journal of Education and Development using Information and Communication Technology, 11(2), 126.

[20] Lakbala, P. (2015). Barriers in implementing eLearningin Hormozgan University of Medical Sciences. Global Journal of Health Science, 8(7), 83. doi:10.5539/gjhs. v8n7p83.

[21] Lalima and Dangwal, K., L. (2017). Blended Learning: An Innovative Approach. Universal Journal of Educational Research, 5(1), 129 - 136. DOI: 10.13189/ujer.2017.050116.

[22] Mahmoodi-Shahrebabaki, M. (2014). ELearningin Iran as a developing country: Challenges ahead and possible solutions. SSRN Electronic Journal. doi:10.2139/ssrn.2514 434.

[23] O’Doherty, D., Dromey, M., Lougheed, J., Hannigan, A., Last, J., \& Mcgrath, D. (2018). Barriers and solutions to online learning in medical education - An integrative review. BMC Medical Education, 18(1). doi:10.1186/s12909-018-1 240-0.

[24] Orlando, J., \& Attard, C. (2015). Digital natives come of age: The reality of today's early career teachers using mobile devices to teach mathematics. Mathematics Education Research Journal, 28, 107-121. doi:10.1007/s13394-015-0 159-6.

[25] Palethorpe, R. (2011). Learning and Development. (fifth edition). London: Chartered Institute of Personnel and Development Published 2009. 400 pp., ISBN: 978184398 2166 UK £41.99. Industrial and Commercial Training, 43(6), 394-395. doi: 10.1108/00197851111160531.

[26] Qureshi, Ijaz., Ilyas, Khola., Yasmin, Robina. \& Whitty, Michael. (2012). Challenges of implementing eLearningin a Pakistani university. Knowledge Management and ELearning. 4. 310-324.

[27] Rajaee, Harandi, S. (2015). Effects of eLearningon students' motivation. 3rd International Conference on Leadership, Technology and Innovation Management. Procedia - Social and Behavioral Sciences 181, 423 - 430 .
[28] Rode, J. A. (2011). Reflexivity in digital anthropology. In Proceedings of the SIGCHI Conference on Human Factors in Computing Systems (pp. 123--132). ACM.

[29] Rohani, S. (2007). 'Teaching of Grammar: Teachers Beliefs, Instructional Contexts and Practices' (Dissertation). UTM, JohorBahru, Johor. Retrieved fromhttp://eprints.usm.my/29 416/1/Teaching_of_grammar.pdf.

[30] Ruliah, Syahrial, Z. and Muchtar, H. (2019). The Computer Assisted Instruction Model Based on a Combination of Tutorial Model and Drill and Practice Model in the Instructional Design of Database Systems in Information Technology Colleges. Universal Journal of Educational Research, 7(9A), 117 - 124. DOI: 10.13189/ujer.2019.0716 14.

[31] Schmidt, S. W., Tschida, C. M., \& Hodge, E. M. (2016) How faculty learn to teach online: What administrators need to know. Online Journal of Distance Learning Administration. Retrieved fromhttp://www.westga.edu/ dis tance/ojdla/spring191/schmidt_tschida_hodge191.html.

[32] Shahnaz, Q., George, P., Son, V., Shabnam, H., Habib, S., Schroeder, J., \& Karim, Q. (2014). Effectiveness of parent education through mobile technology in Afghanistan. Creative Education, 5, 1921-1928. http://dx.doi.org/10.423 6/ce.2014.522215.

[33] Soydal, Irem \& Alır, Gülten \& Ünal, Yurdagül. (2011). Are Turkish universities ready for eLearning: A case of Hacettepe University Faculty of Letters. Information Services and Use. 31. 281-291. 10.3233/ISU-2012-0659.

[34] Stoessel, K., Ihme, T. A., Barbarino, M-L., Fisseler, B., \& Sturmer, S. (2015). Sociodemographic diversity and distance education: Who drops out from academic programs and why? Research in Higher Education, 56, 228-246. doi:10.1007/s11162-014-9343-x.

[35] Uppal, M. A., Ali, S., \& Gulliver, S. R. (2017). Factors determining eLearning service quality. British Journal of Educational Technology, 49(3), 412-426. doi:10.1111/bjet. 12552 .

[36] Wang, Y., Liu, X., \& Zhang, Z. (2018). An overview of eLearningin China: History, challenges and opportunities. Research in Comparative and International Education, 13(1), 195-210. doi:10.1177/1745499918763421.

[37] Zamani, B. E., Esfijani, A., \& Damaneh, S. M. (2016). Major barriers for participating in online teaching in developing countries from Iranian faculty members perspectives. Australasian Journal of Educational Technology. doi:10.14742/ajet.2678.

[38] Zorn, T. (2010). Designing and Conducting Semi-Structured Interviews for Research. Retrievedfromhttp://wmssoros.mn gt.waikato.ac.nz/NR/rdonlyres/em25kkojrnxofpq3j7avsnl46 vkmera63kk2s6nd5ey2pypoxs32ne7dykntjde4u2qhffhpol6 bzi/Interviewguidelines.pdf. 